\title{
AMPHIBIANS OF AN OPEN CERRADO FRAGMENT IN SOUTHEASTERN BRAZIL
}

\author{
Cínthia Aguirre Brasileiro ${ }^{1 * *}$, Ricardo J. Sawaya ${ }^{2}$, Mara C. Kiefer $^{3}$, Marcio Martins $^{4}$ \\ Biota Neotropica v5 (n2) - http://www.biotaneotropica.org.br/v5n2/pt/abstract?article+BN00405022005 \\ Date Received 03/07/2005 \\ Revised 05/06/2005 \\ Accepted 07/01/2005 \\ ${ }^{1}$ Museu de História Natural, Instituto de Biologia, Universidade Estadual de Campinas, C. P. 6109, 13083-970 \\ Campinas SP, and Departamento de Ecologia, Instituto de Biociências, Universidade de São Paulo, \\ Rua do Matão, Trav. 14 s/n, 05508-090 São Paulo SP, Brasil. \\ **Autor para correspondência: cinthia_brasileiro@yahoo.com.br \\ ${ }^{2}$ Laboratório de Herpetologia, Instituto Butantan, Av. Dr. Vital Brazil 1500, 05503-900 São Paulo SP, Brasil \\ ${ }^{3}$ Departamento de Zoologia, Instituto de Biologia, Universidade Estadual de Campinas, C. P. 6109, 13083-970 \\ Campinas SP, Brasil, and Departamento de Ecologia, IBRAG, Universidade Estadual do Rio de Janeiro, \\ Rua São Francisco Xavier 524, Maracanã, 20550-019 Rio de Janeiro, RJ, Brasil. \\ ${ }^{4}$ Departamento de Ecologia, Instituto de Biociências, Universidade de São Paulo, Rua do Matão,
} Trav. 14 s/n, 05508-090 São Paulo SP, Brasil

\begin{abstract}
The Cerrado encompasses ca. 2 million $\mathrm{km}^{2}$ in Brazil. Most Cerrado areas have been greatly disturbed in the past decades. Only $20 \%$ of this biome remain undisturbed, and only $1.2 \%$ is protected. Knowledge on the biology and diversity of Cerrado amphibian assemblages is still incipient. Here we present natural history information (habitat use and reproductive activity) of 28 species of frogs from the Estação Ecológica de Itirapina (EEI), and compare the composition of this assemblage with those of other Cerrado areas, other open areas, and a few forest areas throughout Brazil. We demonstrate that the Itirapina assemblage is more similar to those of other open areas than to those of forests, even when the latter are geographically closer. Six species occurred in the gallery forest at varying levels of dependence (three independent, two semidependent, and one totally dependent) while all other species occurred exclusively in open areas. For most species at EEI, reproduction was strongly synchronized with the onset of the rainy season, with the exception of Hypsiboas lundii, which called throughout the year, and Proceratophrys sp. which started calling prior to the beginning of the rainy season. The spatial and temporal patterns observed in this assemblage seem to reflect both ecological (e. g. hydroperiod of water bodies) and historical factors (e. g. early breeding in leptodactylids, late breeding in hylids, both phylogenetically constrained).

Key words: Amphibians; Habitat use; Reproduction; Cerrado; Itirapina; São Paulo; Brazil
\end{abstract}

\section{Resumo}

O Cerrado originalmente ocupava dois milhões km²no Brasil. Nas últimas décadas, as áreas naturais de Cerrado vêm sendo destruídas rapidamente. Somente $20 \%$ da região original permanece inalterada e apenas 1,2\% encontram-se em unidades de conservação. O conhecimento sobre a biologia e a diversidade de espécies de Cerrado ainda são muito escassos. Neste trabalho, nós apresentamos informações sobre história natural (uso do ambiente e atividade reprodutiva) de 28 espécies de anfíbios da Estação Ecológica de Itirapina (EEI) e comparamos a composição das taxocenoses da EEI com aquelas de outras localidades de Cerrado, e também de áreas florestais e outras fisionomias abertas. Demonstramos que a taxocenose de Itirapina assemelha-se mais àquelas de outras formações vegetais abertas, estruturalmente mais semelhantes, do que as taxocenoses de formações florestais, mesmo que estas sejam geograficamente mais próximas. Seis espécies ocorreram nas matas de galeria em diferentes graus de dependência (três independentes, duas semi-dependentes e uma totalmente dependente) enquanto que as demais ocorreram exclusivamente nas fisionomias abertas. Para a maioria das espécies da EEI, a reprodução foi fortemente sincronizada com a estação chuvosa, com exceção de $H$. lundii, que vocalizou durante todo o ano e Proceratophrys sp. que iniciou as atividades de vocalização antes do início da estação chuvosa. Os padrões espacial e temporal observados nessa taxocenose parecem refletir tanto fatores ecológicos (e. g. hidroperíodo dos corpos d’água) e históricos (e. g. reprodução no início da estação reprodutiva para os leptodactilídeos e tardia para os hilídeos, ambos filogeneticamente determinados).

Palavras-chave: Anfíbios; Uso de ambiente; Reprodução; Cerrado; Itirapina; São Paulo; Brasil

http://www.biotaneotropica.org.br 


\section{INTRODUCTION}

The Cerrado is the second largest vegetational domain in Brazil, encompassing ca. 2 million $\mathrm{km}^{2}$ in the northern, central, western, and southeastern regions of the country (Ratter et al. 1998). In the past decades, natural areas of Cerrado have been greatly disturbed, primarily due to extensive agriculture practice and cattle raising (Ratter et al. 1998). Presently, only $20 \%$ of this biome remains undisturbed, and only $1.2 \%$ is protected (Mittermeier et al. 2000). The Cerrado was recently ranked among the 25 most important terrestrial hotspots (Myers et al. 2000), and is possibly the most threatened tropical savanna in the world (Silva \& Bates 2001). The typical landscape of the Cerrado consists of savanna-like vegetation in the well-drained interfluves and gallery forests along streams and rivers (Ratter et al. 1998). Cerrado vegetation varies in structure and composition (Furley \& Ratter 1998, Ratter et al. 1998). Five main vegetation types of Cerrado are recognized (Eiten 1972, Ratter et al. 1998): cerradão (forest-like savanna), cerrado sensu stricto (woody savanna), campo cerrado (shrubby grassland with trees), campo sujo (shrubby grassland), and campo limpo (grassland).

In 1992, only 2\% of the Cerrado areas in São Paulo State, southeastern Brazil, were represented by grasslands (Kronka et al. 1998). Presently, very few remnants of these open formations are protected. Thus, studies that provide information on the native fauna and flora of open Cerrado formations are of great importance for conservation management and implementation (see Silva \& Bates 2001).

Knowledge on the Cerrado anuran fauna is extremely limited, and most studies were conducted in central and northern Brazil (Moreira \& Barreto 1996, Martins 1998, Strüssmann 2000, Bastos et al. 2003; for a review see Colli et al. 2002). The anuran fauna of the southern regions of the Cerrado is virtually unknown, with the exception of two studies on the herpetofauna of high elevation (> $1500 \mathrm{~m})$ Cerrado areas in central and southern Minas Gerais (Serra do Cipó, Eterovick \& Sazima 2004; and Serra da Canastra, Haddad et al. 1988); furthermore, these areas also include campos rupestres (a shrubby vegetation that grows on rocky fields), which harbors several endemic species of plants and animals.

Here we present natural history information (habitat use and reproductive activity) on 28 species of frogs from the Estação Ecológica de Itirapina (EEI), one of the few remnants of protected grasslands in the State of São Paulo. We also compare the composition of this assemblage with those of other Cerrado sites, two Caatinga (dry, predominantly xerophitic open vegetation), and four forest areas throughout Brazil. We demonstrate that the Itirapina assemblage is more similar to those of other open areas than to those of forests, even when the latter are geographically closer to the EEI.

\section{STUDY AREA}

The Estação Ecológica de Itirapina (ca. 2300 ha) is located in the municipalities of Itirapina and Brotas (Fig. 1; $22^{\circ} 00^{\prime}$ to $22^{\circ} 15^{\prime} \mathrm{S}$; $47^{\circ} 45^{\prime}$ to $48^{\circ} 00^{\prime} \mathrm{W}$; elevation $720-750 \mathrm{~m}$ ). The reserve is covered by well preserved, natural Cerrado vegetation, mainly campo limpo (grasslands), campo sujo (grasslands with scattered shrubs), campo cerrado (grasslands with scattered shrubs and trees), gallery forests, and marshes (Figs. 2 and 3). The soil of the drier interfluves (with grasslands) is primarily composed of sand (over 85\%); soils in wetter areas contain $60-70 \%$ of clay or silt. There are two types of gallery forests in the reserve (Fig. 2): the gallery forest along Lobo stream floods on rare occasions and its soil contains more silt and coarse sand, whereas the gallery forest along Capão stream is flooded throughout the rainy season and the soil contains more clay and fine sand (hydromorphic). Amphibians breed in both permanent and temporary ponds in the EEI and also utilize puddles, streams, swamps, marshes, and large dams as breeding sites (Fig. 4).

The climate is mesothermic with a marked dry season (Fig. 5). In the period from 1998 to 2002, mean monthly rainfall in the dry season (April to September) was $44.2 \mathrm{~mm}$ (0 to $122 \mathrm{~mm}$ each month) and $191.2 \mathrm{~mm}$ during the wet season (October to March; 29 to 452 mm each month). From April 1998 to March 2002, the minimum temperature ranged from 0 to $11^{\circ} \mathrm{C}$ during the dry season, and from 9 to $18{ }^{\circ} \mathrm{C}$ during the wet season; the maximum temperature ranged from 28 to $36^{\circ} \mathrm{C}$ in the dry season, and from 33 to $39{ }^{\circ} \mathrm{C}$ during the wet season (Fig. 5). Occasional frosts occurred in winter, usually in June and July.

\section{MATERIAL AND METHODS}

We surveyed the anurans of EEI from September 1998 to March 2002 using three primary methods: pitfall traps with drift fences (sensu Greenberg et al. 1994, Cechin \& Martins 1999), visual and audio surveys (Heyer et al. 1994), and incidental encounters. All bufonids, leptodactylids, and microhylids were captured or observed using all sampling methods, and hylids were captured using all methods but pitfall traps. Voucher specimens were deposited in the Museu de História Natural da Universidade Estadual de Campinas (ZUEC) and Coleção de Anfíbios da Universidade Estadual Paulista, Rio Claro (CFBH).

In the species accounts, we provided the approximate snout-vent length (SVL, mm) of adult males and females together, unless stated otherwise. We considered rare those species for which we found less than 50 individuals throughout the study, and abundant those for which we found 50 or more individuals during the same period.

We compared the composition of the EEI assemblage with those of five Cerrado sites (Ilha de Maracá, northern Brazil, Martins 1998; Serra da Canastra, southern Brazil, Haddad 


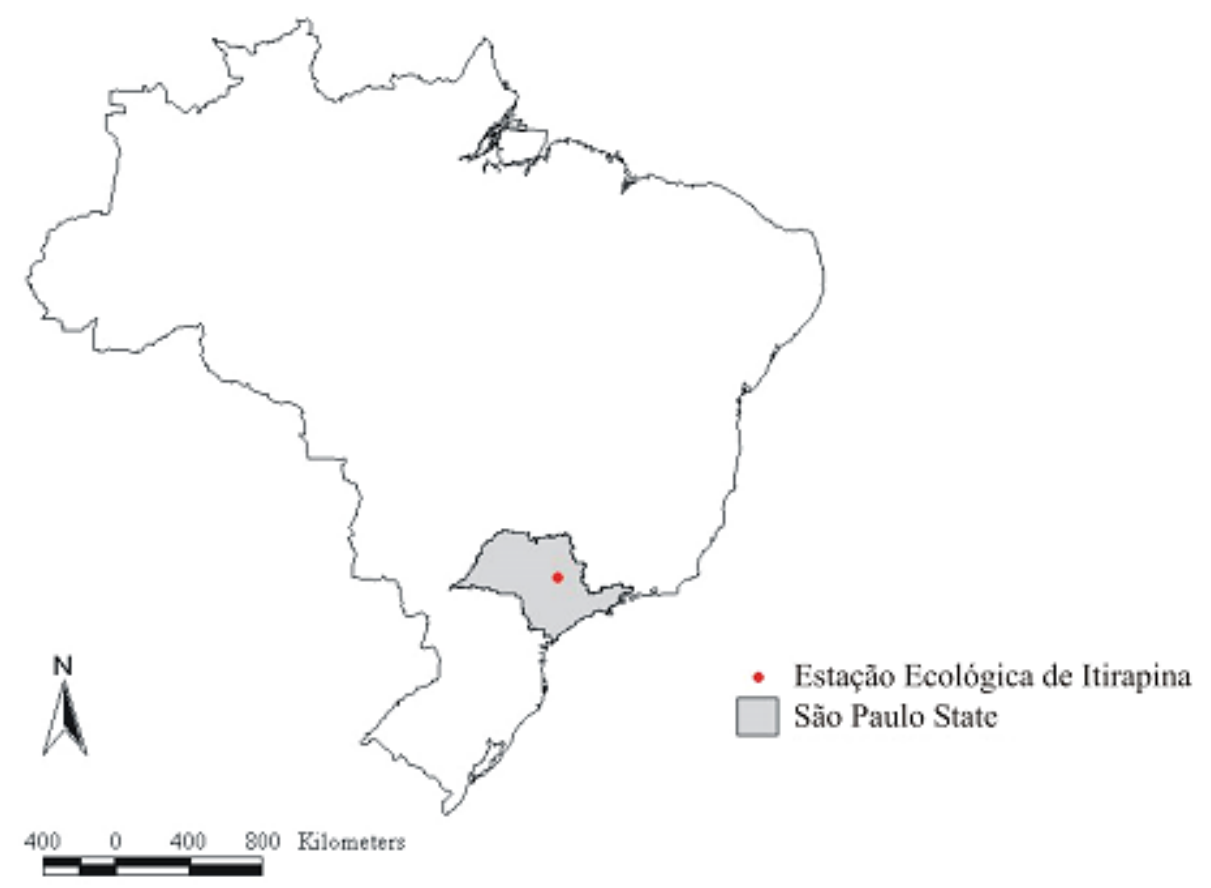

Figure 1 - Map of Brazil with Estação Ecológica de Itirapina (22 $02^{\prime}$ and $22^{\circ} 15^{\prime} S$ and $47^{\circ} 45^{\prime}$ and $48^{\circ} 00^{\prime}$ W), municipalities of Itirapina and Brotas, São Paulo State.

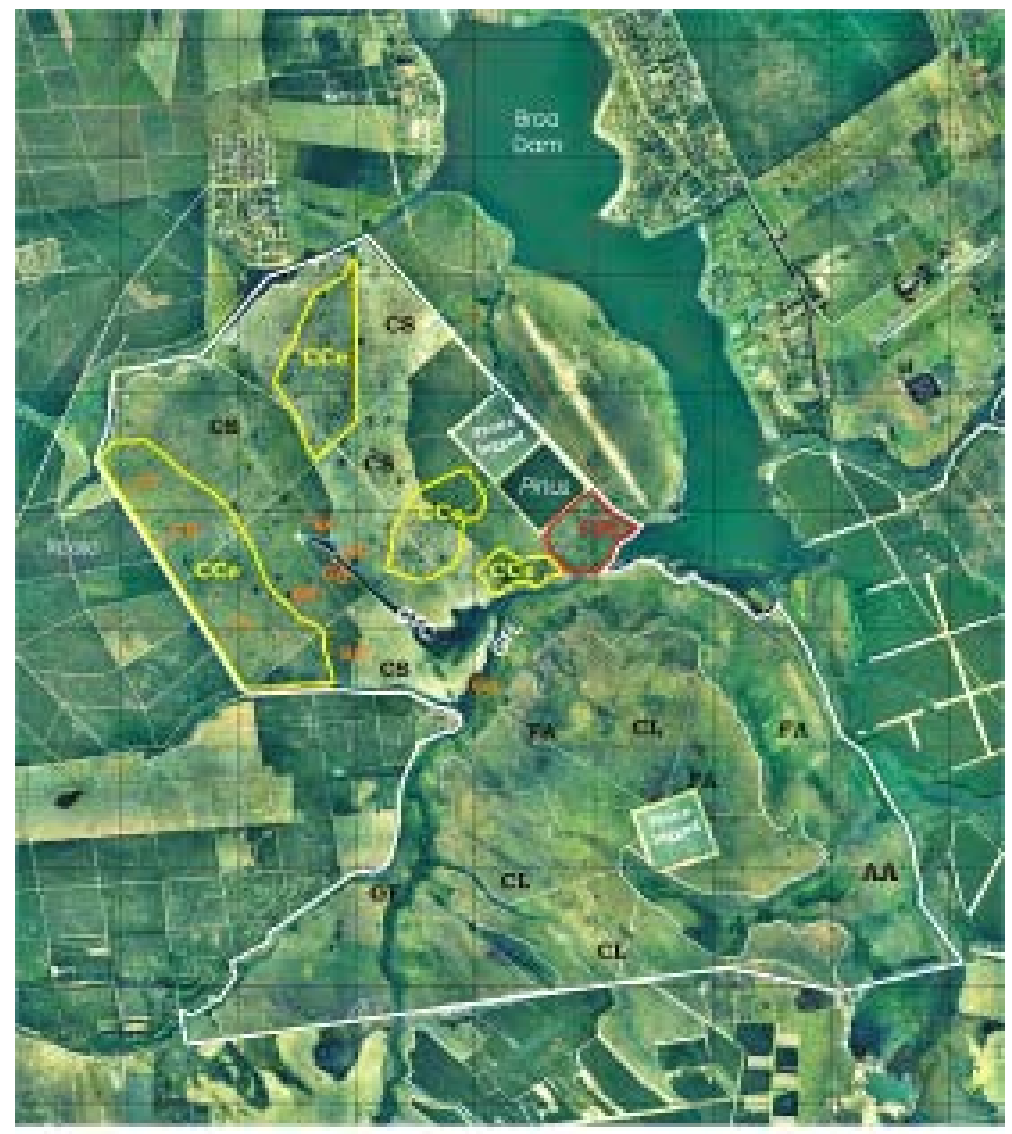

Figure 2 - Aerial photography showing Estação Ecológica de Itirapina taken in 2002. White line = limits of Estação. Physignomies: CSt = cerrado senso stricto; CCe = campo cerrado (yellow line); $C S=$ campo sujo; $C L=$ campo limpo; $A A=$ swamps; GFC= gallery forest along Capão stream; GFL = gallery forest along Lobo stream. GA, GB, GC = pitfall traps in gallery Forest; $S A, S B, S C=$ pitfall traps in campo sujo; $C A, C B, C C$ = pitfall traps in campo cerrado. 

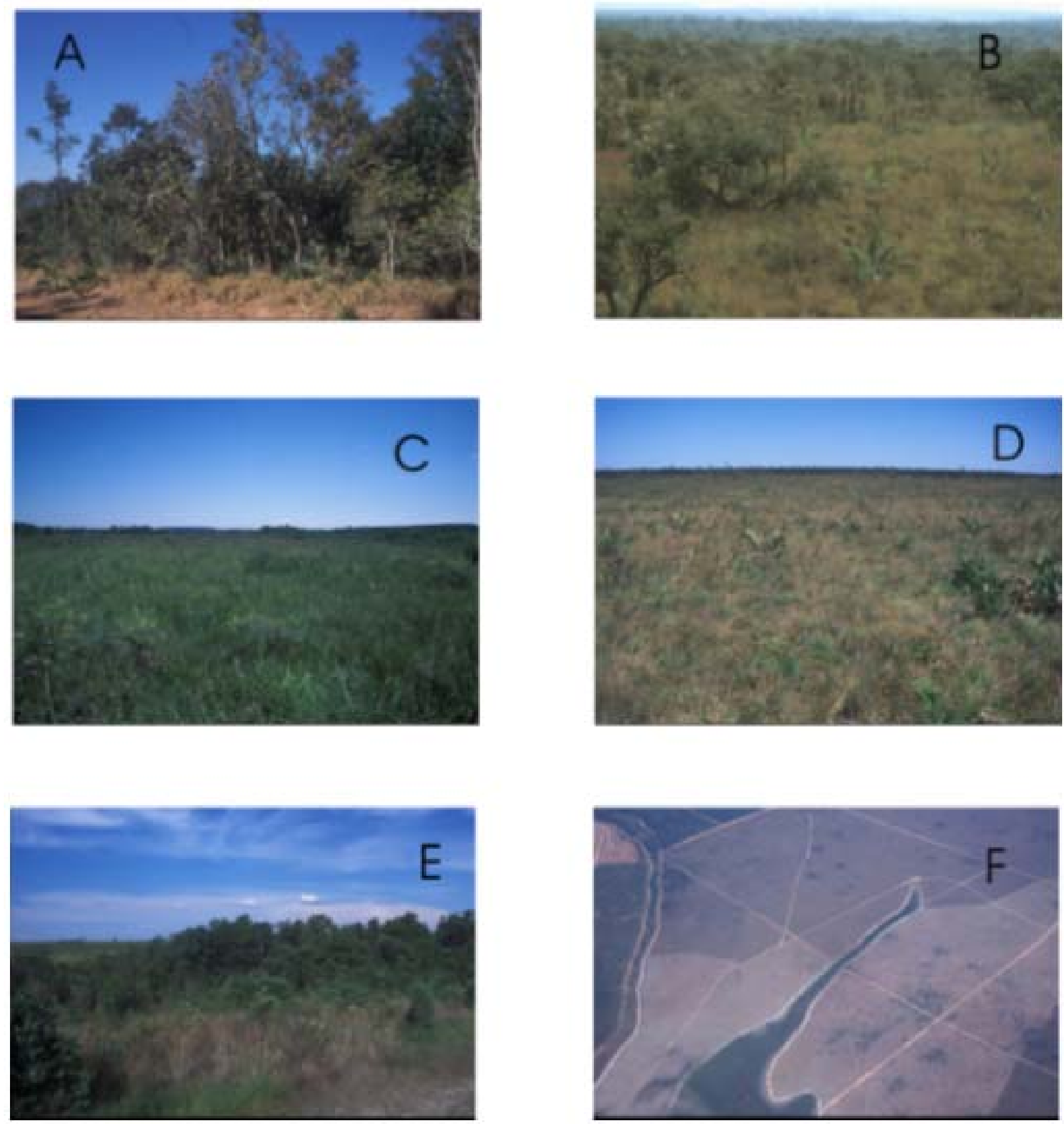

Figure 3 - Physignomies of Estação Ecológica de Itirapina. A - Cerrado senso stricto, B - Campo Cerrado, C - Campo Limpo; D Campo Sujo, $\boldsymbol{E}$ - Swampy areas near gallery Forest; $\boldsymbol{F}$ - Gallery Forest. 

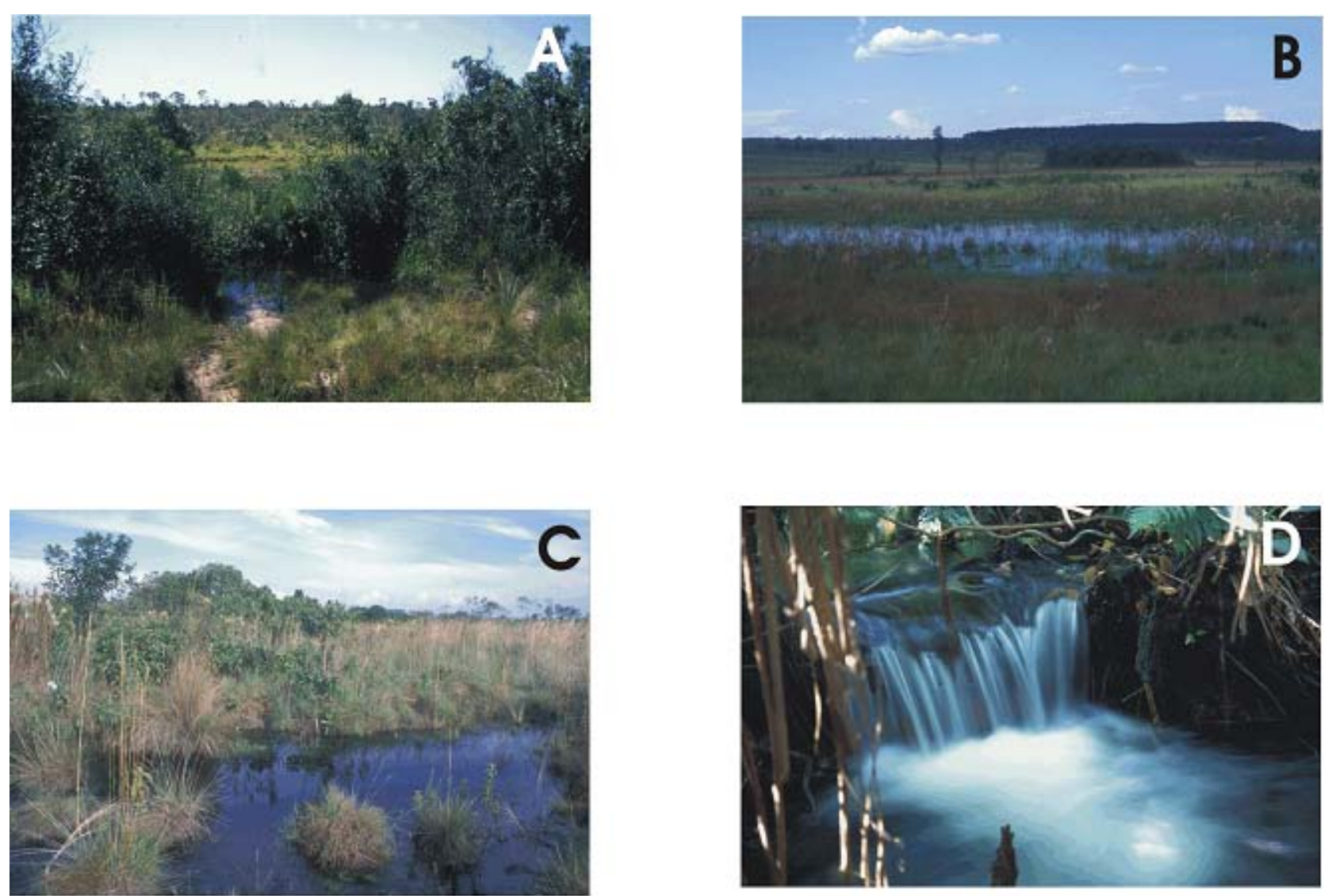

Figure 4 - Some sampled habitats in Estação Ecológica de Itirapina. A- Permanent pond,; B - Temporary pond, Photo: Marcio Martins; C- Temporary pond ; D- Permanent stream, Photos:. (Pictures by Marcio Martins (A and B), Alexandro Tozetti (C), and Ivan Sazima (D).

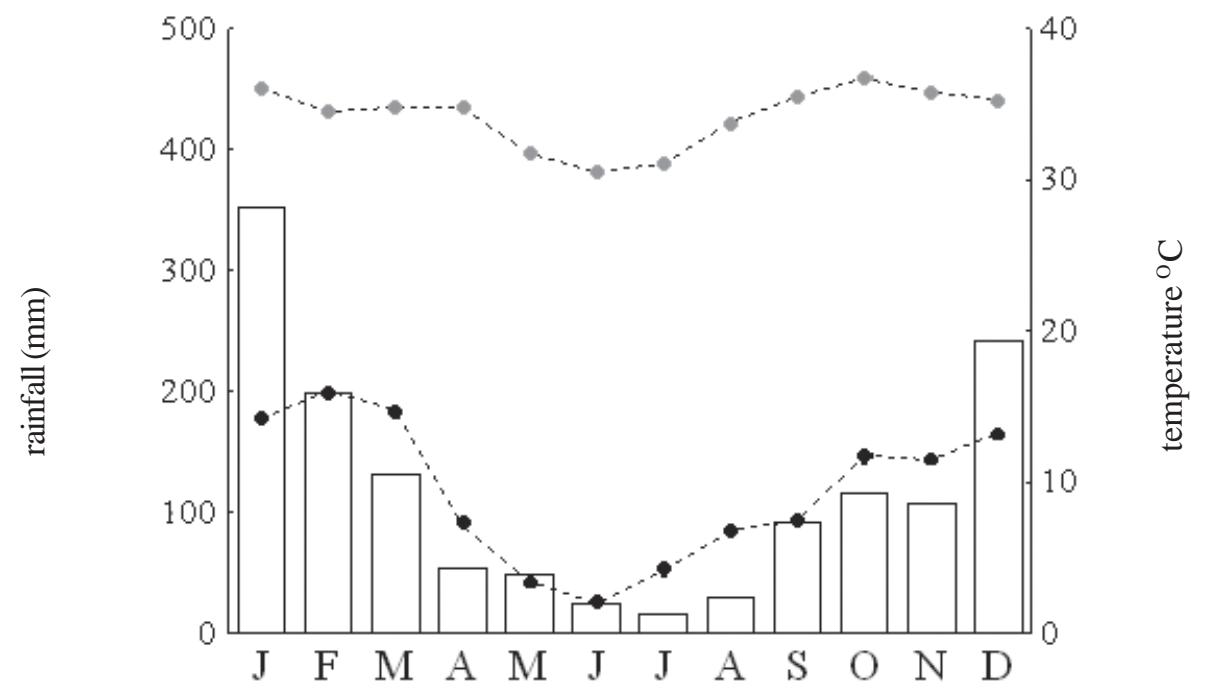

Figure 5 - Mean monthly rainfall (mm; bars), and mean minimum and maximum monthly temperatures ( ${ }^{\circ} \mathrm{C}$; lines) from April 1998 to March 2002 at Estação Ecológica de Itirapina.

http://www.biotaneotropica.org.br 
Family/Species

\begin{tabular}{l}
\hline Bufonidae \\
Bufo ornatus \\
B. schneideri
\end{tabular}

Hylidae

Dendropsophus jimi

Dendropsophus minutus

Dendropsophus nanus

Dendropsophus sanborni

Hypsiboas albopunctatus

Hypsiboas lundii

Hypsiboas faber

Osteocephalus langsdorffi

Scinax cf. berthae

Scinax fuscomarginatus

Scinax fuscovarius

Scinax squalirostris

Scinax cf. similis

Leptodactylidae

Leptodactylus furnarius

Leptodactylus fuscus

Leptodactylus jolyi

Leptodactylus labyrinthicus

Leptodactylus mystacinus

Leptodactylus cf. ocellatus

Physalaemus centralis

Physalaemus cuvieri

Physalaemus fuscomaculatus

Physalaemus nattereri

Proceratophrys sp.

Microhylidae

Chiasmocleis albopunctata

Elachistocleis ovalis
GF,SA

CS,CL,SA

SA

SW,PP,TP

Sep - Jan

SW,PP,TP

Oct - Jan

SA

SW,PP

Sep - Jan

SA

$\mathrm{GF} *$

GF

$-$

GF

CS,CL,SA,GF

CC,CS,CL

CC,CS,CL

CS,CL,SA

CS,CL,SA

CC,CS,SA

SG,CS,CC

CL,CS

CC,CS,CL

CS,CC,CL,SA

CS,CL,SA

CS,CL

CC,CS,CL,AS,GF

CC,CS,CL

CS,CL, CC

CS,GF
Sep - Jan

Sep - Mar

Sep - May **

$\mathrm{PP}$

,SW

Oct - Jan

Jan - Apr

Oct - Mar

Oct - Jan

Sep - Mar
TP

TP,SW

SW

PP,LT,SW

TP,PP,SW

TP,PP

TP,P

TP,PP

TP,P

TP,P

S

TP,P

TP,PP,SW,P

\section{* Mainly in edge gallery forest. - ** In June, July and August, individuals sporadically call.}


et al. 1988; Rio Manso, Strüssman 2001; Silvânia, Bastos et al. 2003; and Água Emendadas, Brandão \& Araújo 1998, all three located in central Brazil), two Caatinga sites (Maturéia and São José do Bonfim, northeastern Brazil, Arzabe 1999), and four forest sites (Manaus, Amazonian forest, northern Brazil, M. Martins unpublished data; Guaraqueçaba, L. M. Castanho unpublished data, Atlantic forest, southeastern Brazil; Intervales, Bertolucci 2001, Atlantic forest, southeastern Brazil; and Ubatuba, C. F. B. Haddad and M. Hartmann, unpublished data, Atlantic forest, southeastern Brazil). For this comparison we used the Sorensen similarity index (Wolda 1981) and the clustering method WPGMA (Sneath \& Sokal 1973), with the software MVSP (Kovach 1999). We use World Wildlife Fund's ecoregions (e. g., Dinerstein et al. 2000) to refer to Brazilian ecosystems.

\section{RESULTS AND DISCUSSION}

\subsection{SPECIES ACCOUNTS}

We recorded 28 species in ten genera and four families at Estação Ecológica de Itirapina (Table 1). The information on each species is detailed below.

We recorded 28 species in ten genera and four families at Estação Ecológica de Itirapina (Table 1). The information on each species is detailed below.

\section{Bufonidae}

\section{Bufo ornatus}

This moderate-sized toad (SVL males $\bar{x}=54.4, \mathrm{SD}=$ $15.7 \mathrm{~mm}, \mathrm{~N}=21$; Fig. 6 ) was a rare species at EEI. No calls were heard at the station, although adults and juveniles were observed and captured in pitfall traps close to the Lobo stream gallery forest during the rainy season. Voucher specimens: ZUEC 12009-10.

\section{Bufo schneideri}

This large toad (SVL males $=136.2, \mathrm{SD}=11.1 \mathrm{~mm} ; \mathrm{N}$ = 6; SVL females $=168.7, \mathrm{SD}=3.8 \mathrm{~mm}, \mathrm{~N}=4$; Fig. 7) was a rare species at EEI. It is an explosive breeder, frequently encountered at the end of the dry season, and early in the rainy season. It was captured mostly in pitfall traps near gallery forests (mainly along Lobo stream), but occasionally observed in campo sujo. It called for a few nights along the margins of large dam along the borders of the reserve during the onset of the rainy season. Additional information on the biology of $B$. schneideri was provided by Moreira \& Barreto (1997), Brandão \& Araújo (1998), and Toledo et al. (2003). Voucher specimen: ZUEC 12012.
Hylidae

Dendropsophus jimi

This small treefrog (SVL males $=19.1, \mathrm{SD}=0.4 \mathrm{~mm}$; $\mathrm{N}=6$; Fig. 8) was very abundant in swampy areas and temporary ponds at EEI. Males called on grasses of these ponds throughout the rainy season; calling sites were 40 to $120 \mathrm{~cm}$ above the ground. Some males were observed using the same calling site over multiple nights. Tadpoles were found in temporary ponds. Voucher specimen: ZUEC 12047.

\section{Dendropsophus minutus}

This small treefrog (SVL males $=21.0, \mathrm{SD}=0.9 \mathrm{~mm}$; $\mathrm{N}=8$; Fig. 9) was very common in swampy areas and temporary ponds throughout the reserve. Males called on the vegetation (usually grasses and shrubs) from 30 to $80 \mathrm{~cm}$ above ground, throughout the rainy season. Tadpoles were common in these ephemeral water bodies. Additional information on the biology of $D$. minutus was provided by Cardoso \& Haddad (1984) and Eterovick \& Sazima (2004). Voucher specimens: ZUEC 12042-43.

\section{Dendropsophus nanus}

This diminutive treefrog (SVL males $=20.4, \mathrm{SD}=0.8$ $\mathrm{mm} ; \mathrm{N}=10$ ) was common in large flooded areas. Males called on grasses and shrubs from 10 to $40 \mathrm{~cm}$ above ground throughout the rainy season. Additional information on its biology was provided by Rossa-Feres \& Jim (2001) and Toledo et al. (2003). Voucher specimen: ZUEC 12041.

\section{Dendropsophus sanborni}

A diminutive treefrog (SVL males $=17.3, \mathrm{SD}=1.4$ $\mathrm{mm} ; \mathrm{N}=6$; Fig. 10) frequently encountered in swamps, large flooded areas, and ponds. Males called from the vegetation 30 to $60 \mathrm{~cm}$ above ground throughout the rainy season. Additional information on its biology was provided by Rossa-Feres \& Jim (2001) and Toledo et al. (2003). Voucher specimens: ZUEC 12039-40.

\section{Hypsiboas albopunctatus}

This moderate-sized treefrog (SVL males $=53.1, \mathrm{SD}=$ $7.2 \mathrm{~mm}$; $\mathrm{N}=6$; Fig. 11) was very abundant in permanent or long lasting ponds and swampy areas around both gallery forests. It called from low branches of shrubs and low trees, and was found mostly from 30 to $100 \mathrm{~cm}$ above ground. Calling activity occurred throughout the rainy season, but peaked at the end of the season. Tadpoles were found in permanent ponds. Additional information on the biology of $H$. albopunctatus was provided by Moreira \& Barreto (1997) and Toledo et al. (2003). Voucher specimens: ZUEC 12013-14. 


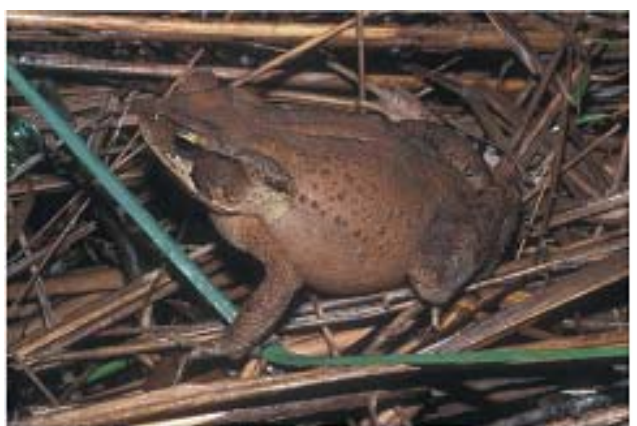

Figure 6 - Bufo ornatus

Bufonidae. Photo: Ricardo J. Sawaya

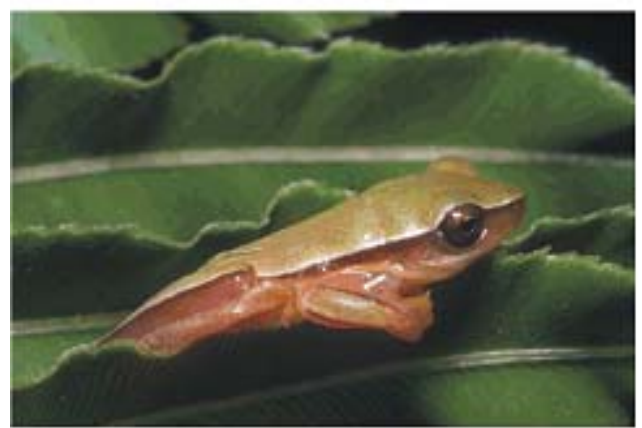

Figure 8 - Dendropsophus jimi

Hylidae. Photo: Ricardo J. Sawaya

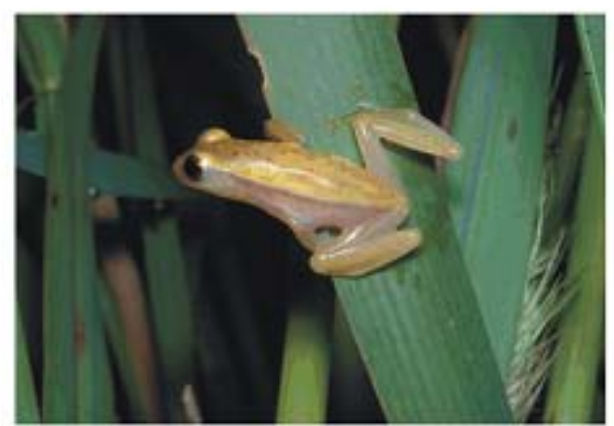

Figura 10 - Dendropsophus sanborni Hylidae. Photo: Ivan Sazima

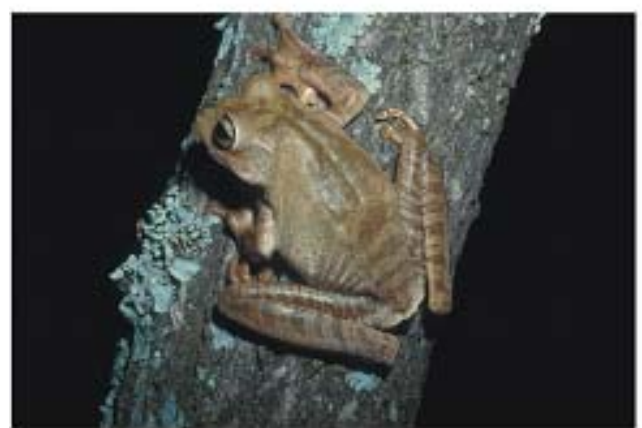

Figure 12 - Hypsiboas faber Hylidae. Photo Ricardo J.Sawaya

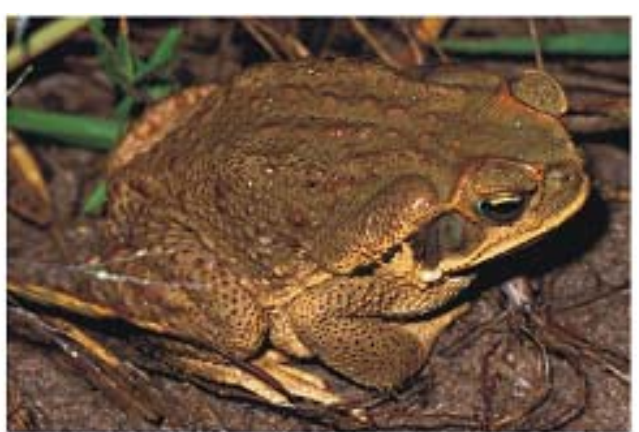

Figure 7 - Bufo schneideri

Bufonidae. Photo: Ricardo J. Sawaya

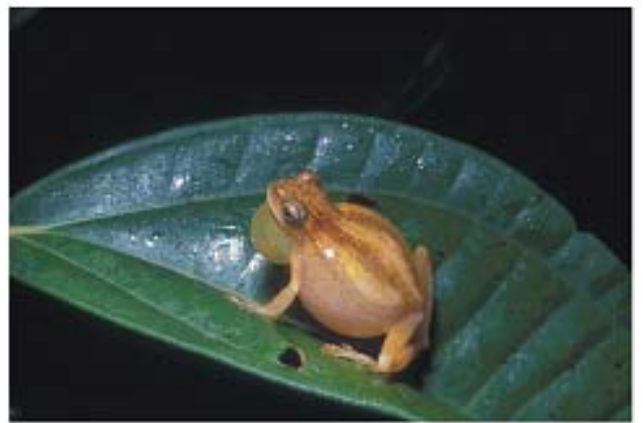

Figura 9 - Dendropsophus minutus

Hylidae. Photo: Alexandro Tozetti

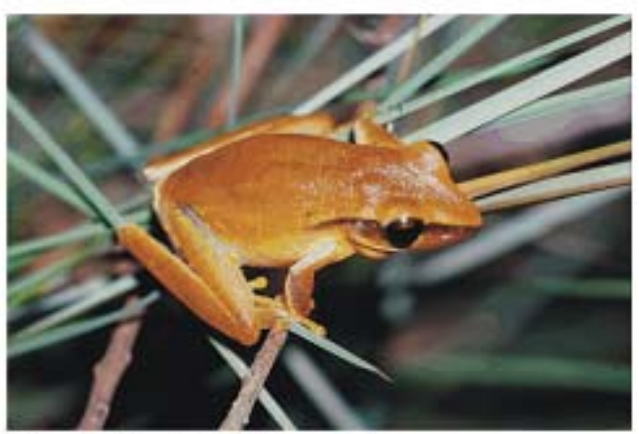

Figure 11 - Hypsiboas albopunctatus

Hylidae. Photo:Alexandro Tozetti

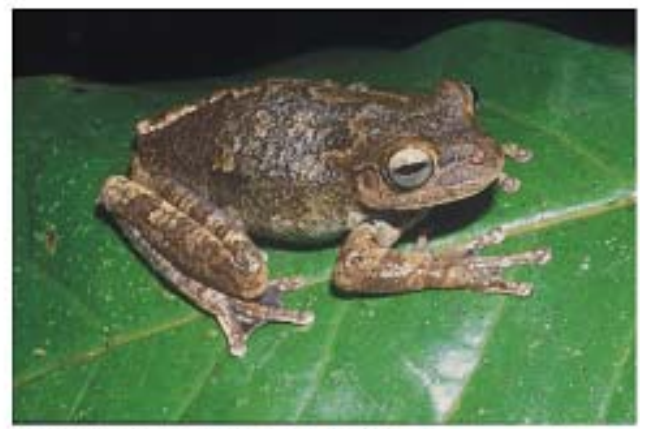

Figure 13 - Hypsiboas lundii

Hylidae. Photo: Alexandro Tozetti 


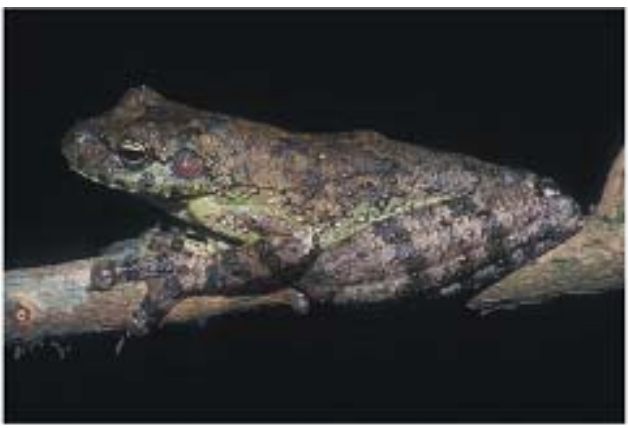

Figure 14 - Osteocephalus lagsdorfii Hylidae. Photo: Ricardo J. Sawaya

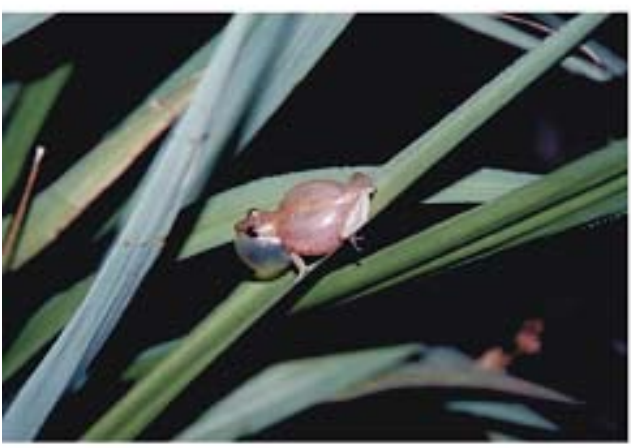

Figure16 - Scinax fuscomarginatus Hylidae.Photo: Luis FelipeToledo

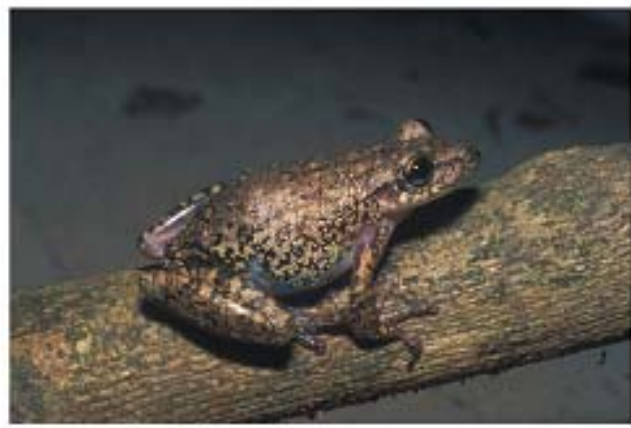

Figure 18 -Scinax ef. similis Hylidae. Photo: Marcio Martins

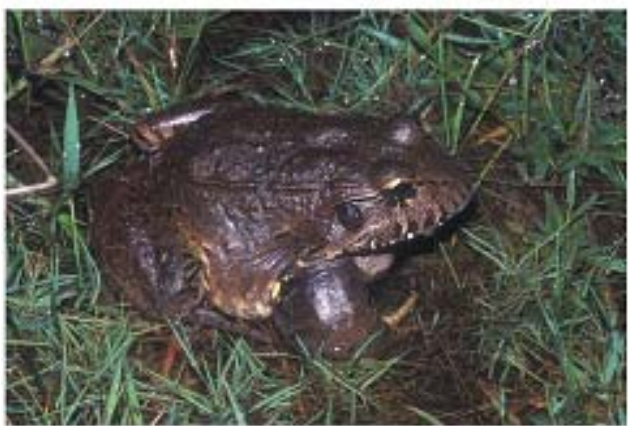

Figure 20- Leptodactylus labyrinthicus Leptodactylidae. Photo: Ricardo J. Sawaya

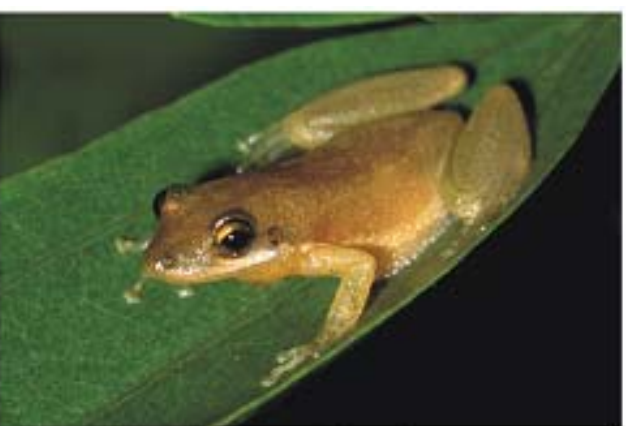

Figure 15 - Scinax ef. berthae

Hylidae. Photo: Marcio Martins

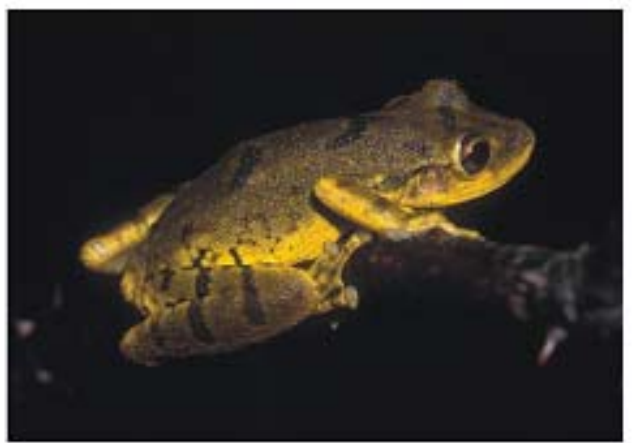

Figure 17 - Scinax fuscovarius

Hylidae. Photo: Marcio Martins

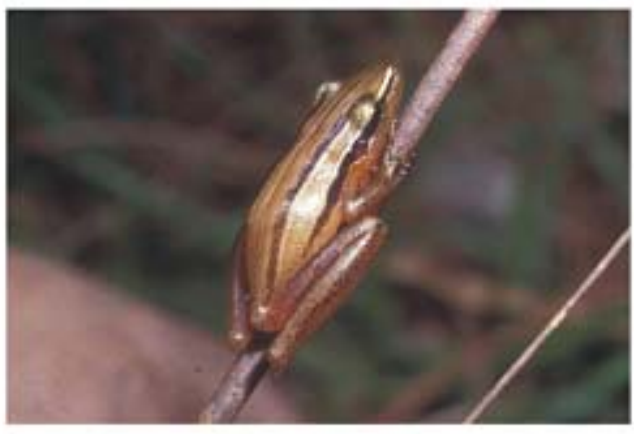

Figure 19 - Scinax squalirostris

Hylidae. Photo: Marcio Martins

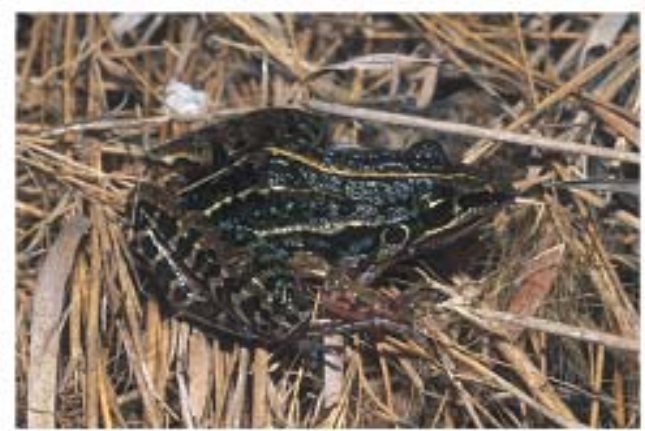

Figure 21 - Leptodactylus furnarius

Leptodactylidae. Photo: Ricardo J. Sawaya 


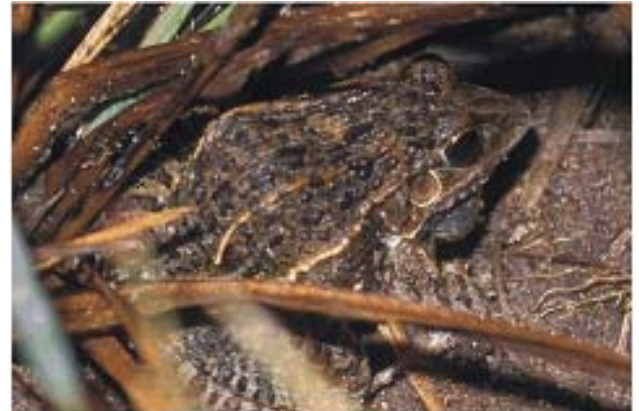

Figure 22 - Leptodactylus fuscus

Leptodactylidae.Photo: Marcio Martins

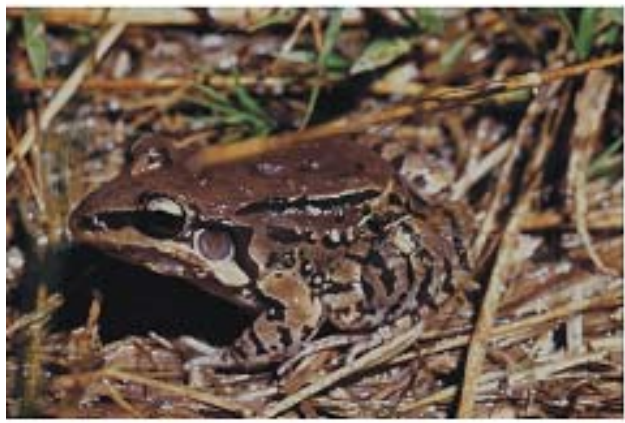

Figure 24 - Leptodactylus mystacinus Leptodactylidae. Photo: Alexandro Tozetti

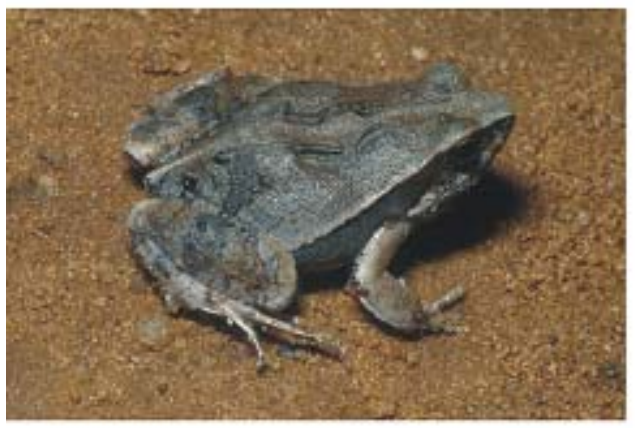

Figure 26 - Physalaemus centralis Leptodactylidae. Photo: Ricardo J. Sawaya

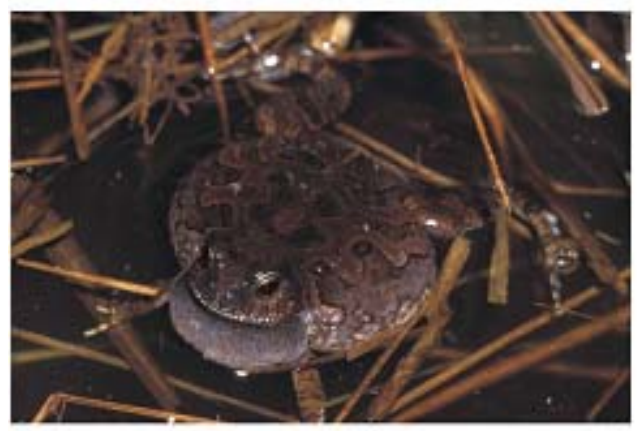

Figure 28 - Physalameus fuscomaculatus Leptodactylidae. Photo: Marcio Martins

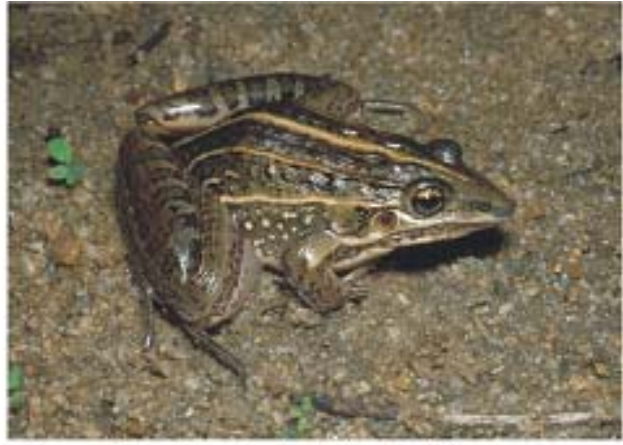

Figure 23 - Leptodactylus jolyi

Leptodactylidae.Photo: Ivan Sazima

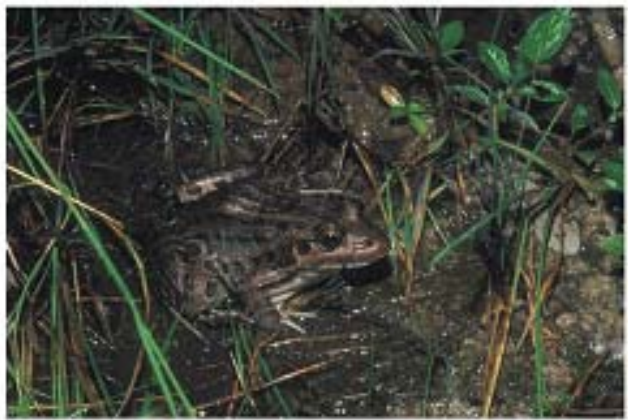

Figure 25 - Leptodactylus ef. ocellatus

Leptodactylidae. Photo: Alexandro Tozetti

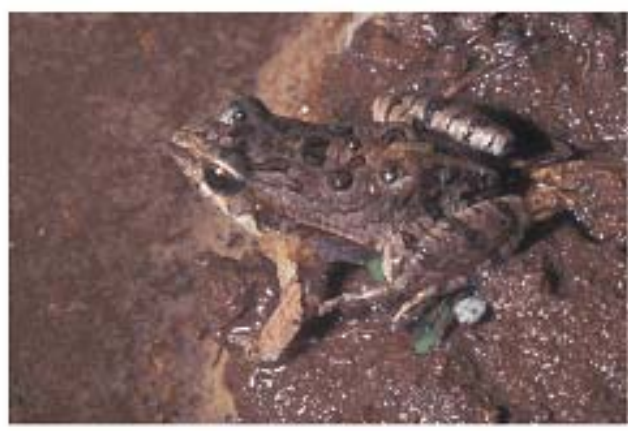

Figure 27 -Physalaemus cuvieri

Leptodactylidae.Photo: Alexandro Tozetti

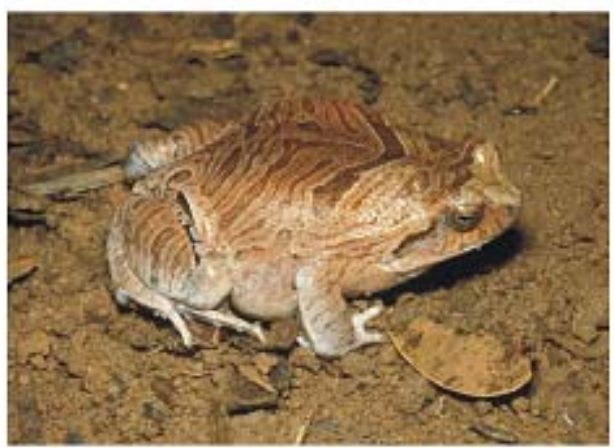

Figure 29 - Physalameus nattereri Leptodactylidae.Photo: Ivan Sazima 


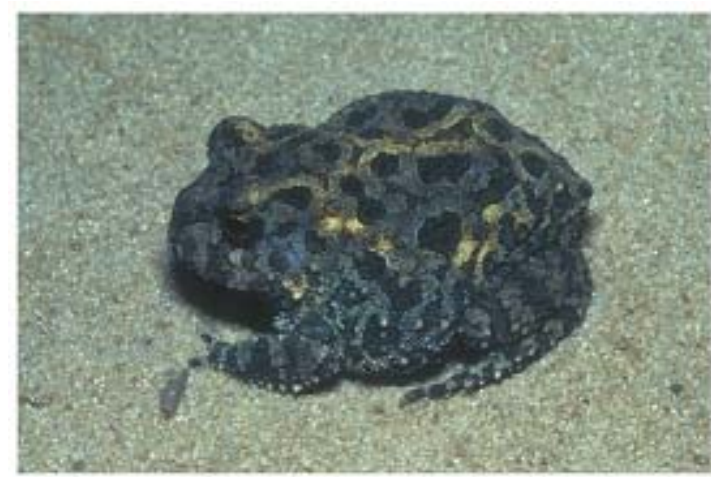

Figure 30 - Proceratophrys spn

Leptodactylidae Photo: Alexandro Tozetti

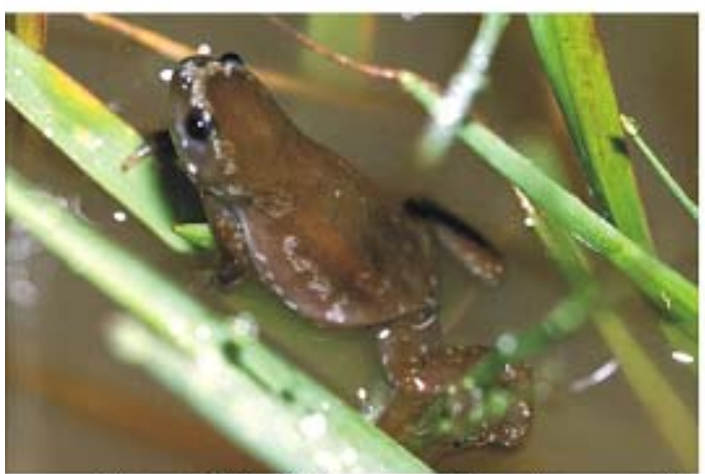

Figure 32 - Chiasmocleis albopunctata Microhylidae. Photo: Marcio Martins

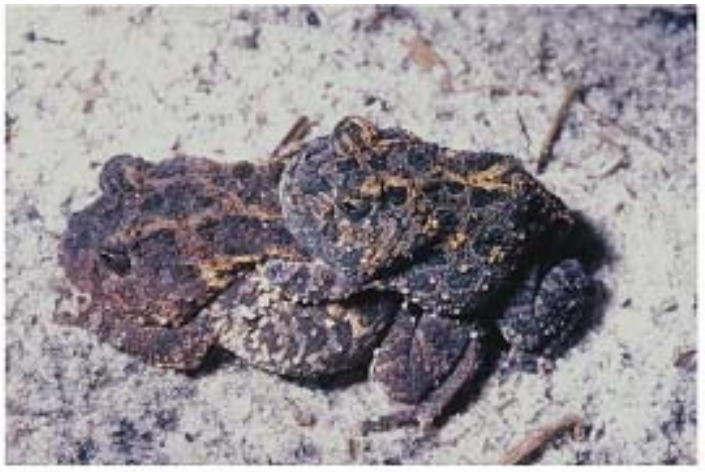

Figure 31 - Proceratophrys spn Leptodactylidae - Amplectant Photo: Alexandro Tozetti

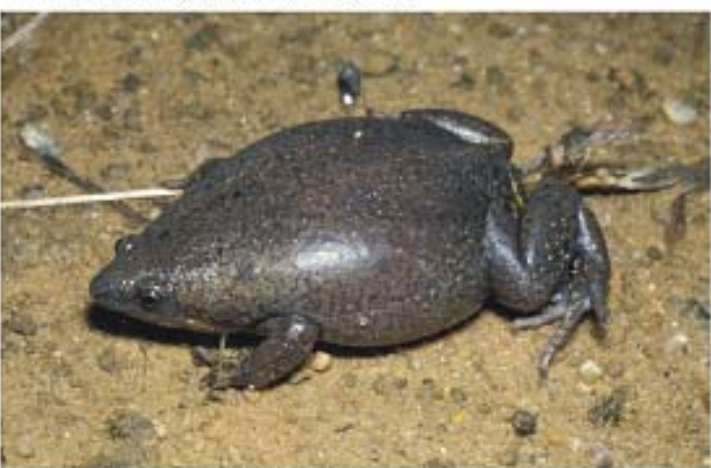

Figure 33 - Elachistocleis ovalis

Microhylidae. Photo: Ivan Sazima

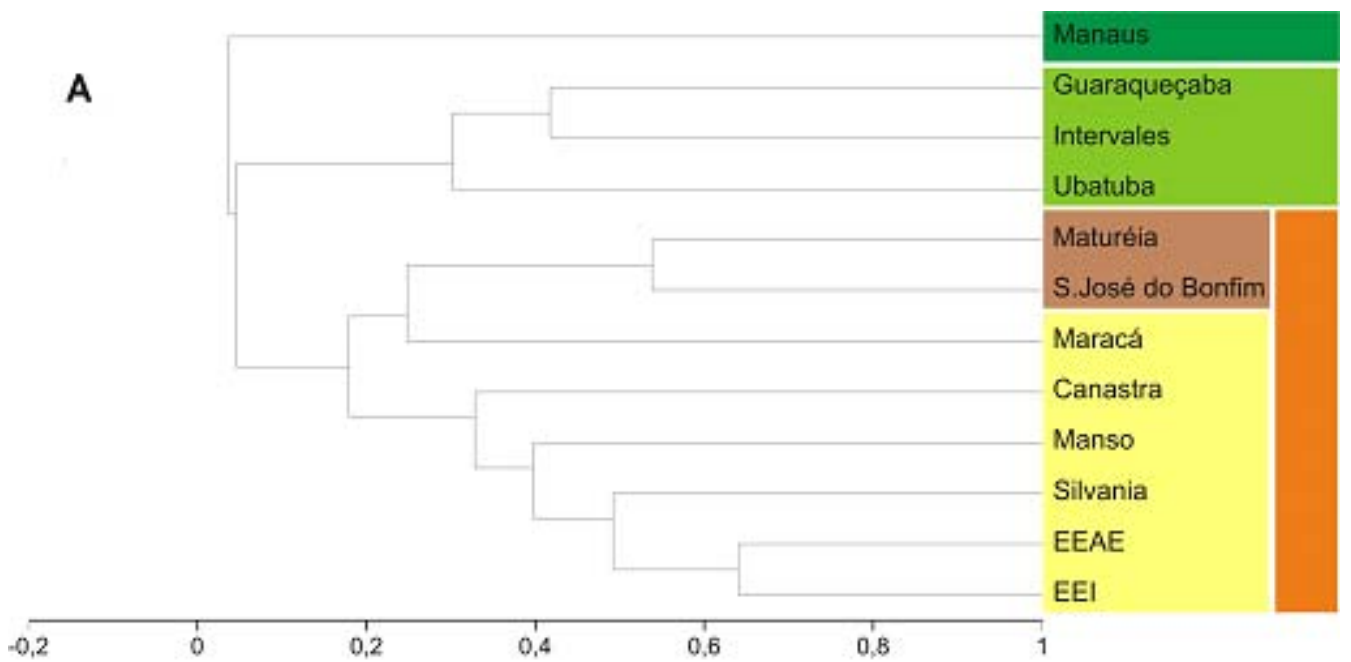

Figure 34- A - Dendrogram for the cluster analysis of seven amphibian assemblages in open areas and five in forest areas: Amazônia Central, Manaus (AM); Cerrado de Manso (MT); Estação Ecológica de Águas Emendadas (EEAE, DF); Estação Ecológica de Itirapina (SP), Guaraqueçaba (PR); Ilha de Maracá (RR); Intervales (SP); Serra da Canastra (MG); Ubatuba (SP), São José do Bonfim (PB) and Maturéira (PB). Coefficient of Sorensen and cluster analysis "WPGMA”. 
B

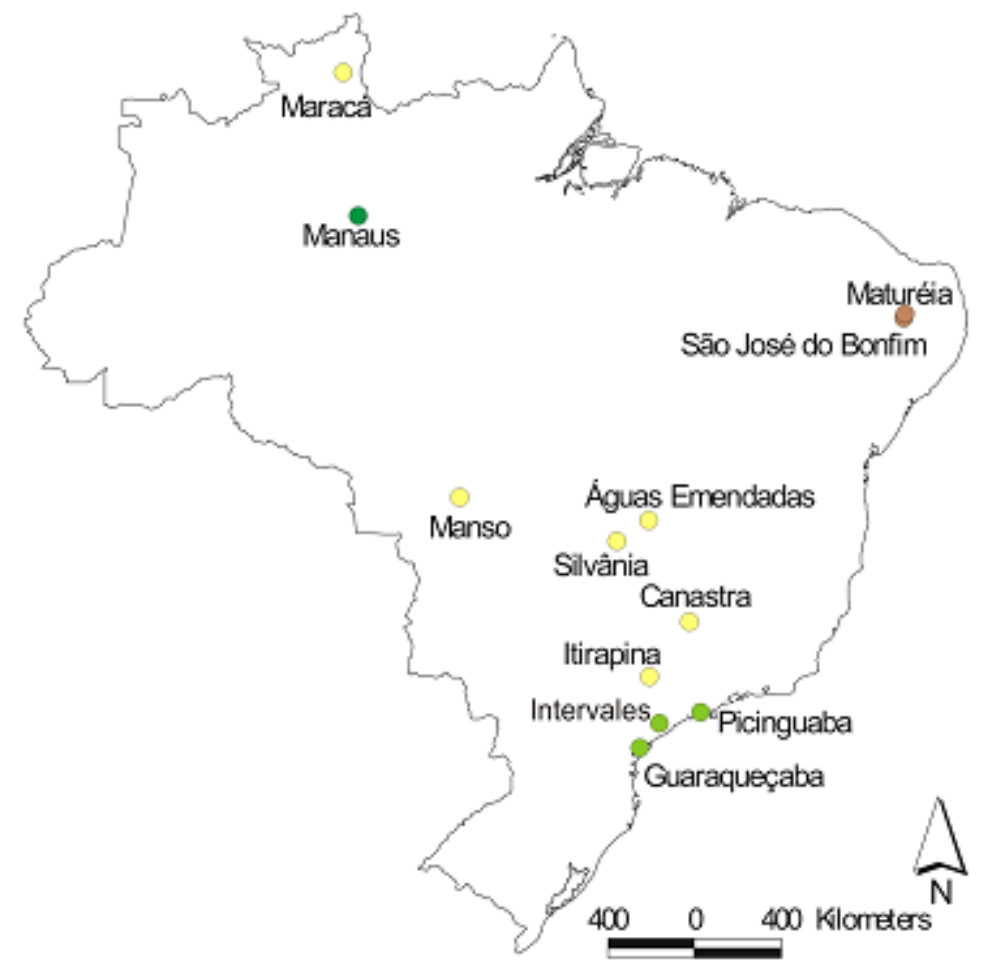

Figure 34 -B - Map of selected areas: Yellow = Cerrado; Brown = Caatinga; Olive Green = Atlantic Forest; e Dark Green = Amazonian forest.

\section{Hypsiboas faber}

A single adult of this large species (SVL $=87.3 \pm 5.4$ $\mathrm{mm} ; \mathrm{N}=5$; Fig. 12) was heard on the border of the reserve, in a disturbed area of campo limpo. This species is common in permanent ponds outside the reserve. Additional information on its biology was provided by Martins \& Haddad (1988), Martins (1993a, b), and Martins et al. (1993, 1998). Voucher specimen: ZUEC 12024.

\section{Hypsiboas lundii}

This large species (SVL males $=65.4, \mathrm{SD}=1.0 \mathrm{~mm}$; $\mathrm{N}=3$; Fig. 13) was found only along the gallery forest of Capão stream, where up to 13 males could be heard in a single night. Males called from the vegetation, from 1.5 to $10.0 \mathrm{~m}$ above the ground (approximately the height of the canopy), throughout the rainy season and occasionally in the dry season. Juveniles were also found in gallery forests. Additional information on the biology of $H$. lundii was provided by Eterovick \& Sazima (2004). Voucher specimens: ZUEC 12034-35.

\section{Osteocephalus langsdorffii}

A single individual (adult female) of this large treefrog (Fig. 14) was captured in the gallery forest of Lobo stream. The call was never heard inside the reserve. However, we found a large breeding population in a flooded area along a stream outside the reserve (cf. Almeida \& Nunes 1999). Voucher specimen: ZUEC 12025.

\section{Scinax cf. berthae}

This small treefrog (SVL males $=18.4, \mathrm{SD}=1.5 \mathrm{~mm} ; \mathrm{N}$ $=6$, Fig. 15) was found in swampy areas and at the edge of gallery forests. Males called from the beginning to the middle of the rainy season. Voucher specimen: ZUEC 12044.

\section{Scinax fuscomarginatus}

This small treefrog (SVL males $=20.1 \pm 1.4 \mathrm{~mm}$; N $=5$. Fig.16) was relatively common in swampy areas and temporary ponds throughout the reserve. Males called from the middle to the end of the rainy season. Calling 
sites were up to $30 \mathrm{~cm}$ above the ground. Additional information on its biology was provided by Moreira \& Barreto (1997) and Rossa-Feres \& Jim (2001). Voucher specimens: ZUEC 12037-38.

\section{Scinax fuscovarius}

This moderate-sized treefrog (SVL males $=43.3, \mathrm{SD}=$ $2.4 \mathrm{~mm}$; $\mathrm{N}=6$; Fig. 17) was very abundant in swampy areas, temporary ponds, and on the edge of gallery forests. It was found in all vegetation types. Males called on the ground or from vegetation 10 to $40 \mathrm{~cm}$ above the ground. Calling activity occurred throughout the rainy season. Additional information on the biology of $S$. fuscovarius was provided by Rossa-Feres \& Jim (2001) and Eterovik \& Sazima (004). Voucher specimen: ZUEC 12046.

\section{Scinax cf. similis}

This moderate-sized treefrog (SVL males $=39.0, \mathrm{SD}=$ $2.1 \mathrm{~mm}, \mathrm{~N}=197$; SVL females = 36.7, SD = $2.7 \mathrm{~mm}$; $\mathrm{N}=120$; Fig. 18) was commonly found in temporary ponds throughout the reserve; males called throughout the rainy season, with peaks of activity after heavy rains. Males called from vegetation 10 to $50 \mathrm{~cm}$ above ground. Thousands of amplectant pairs were observed in one night in a single pond in December 2001. Information on the biology of Scinax similis was provided by Rossa-Feres \& Jim (2001). Voucher specimen: ZUEC 12045.

\section{Scinax squalirostris}

This small treefrog (SVL males $\mathrm{x}=21.1, \mathrm{SD}=2.0 \mathrm{~mm}$; $\mathrm{N}=5$; Fig. 19) was a common species in some temporary ponds at EEI. Males called during the beginning of the rainy season, mainly on grass tufts about $50 \mathrm{~cm}$ above the ground. Additional information on its biology was provided by Eterovick \& Sazima (2004). Voucher specimen: ZUEC 12036.

\section{Leptodactylidae}

\section{Leptodactylus furnarius}

This moderate-sized frog (SVL males $=34.6, \mathrm{SD}=3.2$ mm; $\mathrm{N}=28$; SVL females = 37. 6, $\mathrm{SD}=4.3 \mathrm{~mm} ; \mathrm{N}=24$; Fig. 21 ) was captured in pitfall traps in all vegetation types, although it was more abundant in swampy areas along gallery forests. It calls in the middle of the rainy season and digs burrows in the drier areas of temporary ponds and swamps, where foam nests were deposited. Additional information on the biology of $L$. furnarius was provided by Giaretta \& Kokobum (2003) and Eterovick \& Sazima (2004). Voucher specimen: ZUEC 12028.

\section{Leptodactylus fuscus}

This moderate-sized frog (SVL males $=47.2, \mathrm{SD}=4.8$ $\mathrm{mm} ; \mathrm{N}=35$; SVL females $=56.4, \mathrm{SD}=4.8 \mathrm{~mm} ; \mathrm{N}=22$; Fig. 22) was common in all vegetation types and was observed or captured by all methods. Calling adults and dug-out burrows (where foam nests were deposited) were found in the drier surroundings of temporary ponds at the beginning and during the middle of the rainy season. This species was not found during the dry season. Additional information on the biology of L. fuscus was provided by Martins (1988), Rossa-Feres et al. (1999), and Freitas et al. (2001). Voucher specimen: ZUEC 12021.

\section{Leptodactylus jolyi}

This moderate-sized frog (SVL males $=45.0, \mathrm{SD}=1.3$ $\mathrm{mm} ; \mathrm{N}=6$; Fig. 23) was registered in swampy areas near temporary ponds in campo limpo. Males generally called from sheltered places (base of grass tufts) at the beginning of and middle of the rainy season. Additional information on its biology was provided by Eterovick \& Sazima (2004). Voucher specimen: CFBH6514.

\section{Leptodactylus labyrinthicus}

During the rainy season, males and females of this large frog (SVL males = 150.8, SD = $26.5 \mathrm{~mm} ; \mathrm{N}=6$; $\mathrm{SVL}$ females; = 138.1, $\mathrm{SD}=7.2 \mathrm{~mm}$; $\mathrm{N}=3$; Fig. 20) were common in all vegetation types, in swamps close to gallery forests, and in large temporary ponds in areas of campo limpo and campo sujo. Males always called at ground level. Foam nests and tadpoles were abundant in water-filled mammal burrows and natural depressions on the ground. Females were frequently observed caring for their clutches. During the dry season, adults forage at night in campo sujo, and hide in mammal burrows during the day and night. Frogs of all stages post-metamorphosis (from froglets to large adults) were frequently captured in pitfall traps in gallery forest, and less frequently in campo sujo. Tadpoles and juveniles were common in and around swamps and ponds. Voucher specimens: ZUEC 12026-27.

\section{Leptodactylus mystacinus}

This moderate-sized frog (SVL males $=47.2 \mathrm{~mm} \pm 4.8$ $\mathrm{mm} ; \mathrm{N}=35$; $\mathrm{SVL}$ females $=56.4, \mathrm{SD}=4.8 \mathrm{~mm} ; \mathrm{N}=22$; Fig. 24) was captured in pitfall traps in all vegetation types, although it was found mainly in campo cerrado. Overall abundance is low at EEI (compared to L . fuscus and $L$. furnarius). Dug-out burrows (where foam nests were deposited) and calling adults were found at the beginning and throughout the middle of the rainy season, in the drier regions of temporary ponds and swamps (e.g. Lucas, 2004) Voucher specimen: ZUEC 12015. 
Leptodactylus cf. ocellatus

This large frog (SVL males $=71.1, \mathrm{SD}=13.8 \mathrm{~mm} ; \mathrm{N}=$ 3; Fig. 25) was rare at EEI, found only around ponds and swamps along gallery forests. On one occasion, a school of tadpoles guarded by a female was found in a large temporary pond. Voucher specimen: ZUEC 12029.

\section{Physalaemus centralis}

This moderate-size frog (SVL males $=31.1, \mathrm{SD}=3.8$ $\mathrm{mm} ; \mathrm{N}=5$; Fig. 26) was rare, although it was found in all vegetation types. Calling males, egg clutches, and tadpoles were found at the beginning and throughout the middle of the rainy season in temporary ponds and swamps (CAB, unpubl. data). Voucher specimens: ZUEC 12018-19.

\section{Physalaemus cuvieri}

This small frog (SVL males $=27.6, \mathrm{SD}=3.0 \mathrm{~mm} ; \mathrm{N}=$ 525; SVL females $=29.5, \mathrm{SD}=2.7 \mathrm{~mm} ; \mathrm{N}=680$; Fig. 27) was the most abundant leptodactylid at EEI; it was captured in pitfall traps in all vegetation types. Males generally called from sheltered places (base of grass tufts) in temporary ponds throughout the rainy season. Males also called from small puddles after heavy rains. Tadpoles and juveniles were very commonly found in and around temporary ponds. Additional information on the biology of $P$. cuvieri was provided by Bokermann (1962), Cardoso (1981), and Barreto \& Andrade (1995). Voucher specimen: ZUEC 12020.

\section{Physalaemus fuscomaculatus}

This moderate-size frog (SVL males $=32.8, \mathrm{SD}=3.8$ mm; $\mathrm{N}=20$; SVL females = 37.8, SD = 4.4 mm; N=23; Fig. 28) was very abundant at EEI. It was commonly captured in pitfall traps from all habitats sampled, except along gallery forests. It called in all types of temporary water bodies after heavy rains during both the dry and wet season. Generally males called floating in small sheltered puddles (Fig. 27). Amplectant pairs were found from 21:00 to 22:00h ( $\mathrm{N}=8$ ) and egg laying (in foam nests) was observed at approximately 02:00h $(\mathrm{N}=6)$. Tadpoles were commonly found in temporary water bodies. Additional information on the biology of $P$. fuscomaculatus was provided by Rossa-Feres \& Jim (2001) and Giaretta \& Menin (2003). Voucher specimens: ZUEC 12016-17.

\section{Physalaemus nattereri}

This moderate-sized species (SVL males $=37.8, \mathrm{SD}=$ $4.5 \mathrm{~mm} ; \mathrm{N}=51$; $\mathrm{SVL}$ females $=43.0, \mathrm{SD}=6.3 \mathrm{~mm}=7$; Fig. 29 ) was relatively rare at EEI. It was captured in pitfall traps in all habitats with the exception of gallery forest. Males called after heavy rains throughout the rainy season from various types of temporary water bodies. Generally males called float- ing in small sheltered puddles. Amplectant pairs were observed at approximately 22:00h $(\mathrm{N}=6)$, and eggs were deposited after 2:00h $(\mathrm{N}=5)$. Additional information on the biology of $P$. nattereri was provided by Rossa-Feres \& Jim (2001). Voucher specimens: ZUEC 12022-23.

\section{Proceratophrys sp.}

This moderated frog $($ SVL males $=28.0, \mathrm{SD}=3.1 \mathrm{~mm}$, $\mathrm{N}=65$; SVL females = 36.6, $\mathrm{SD}=4.9 \mathrm{~mm} ; \mathrm{N}=75$; Fig. 30 e 31) was abundant at EEI. It was found in the gallery forest of Capão stream and in campo sujo. It called manly after heavy rains throughout the rainy season. Males called during daytime. Voucher specimen: ZUEC 13021

\section{Microhylidae \\ Chiasmocleis albopunctata}

Although rarely captured by pitfall traps, this diminutive frog $(\mathrm{SVL}$ males $=25.3, \mathrm{SD}=2.1 \mathrm{~mm} ; \mathrm{N}=6$; $\mathrm{SVL}$ females $=29.1$, SD = $3.2 \mathrm{~mm}$; N =12; Fig. 32) was found in all vegetation types. Large aggregations of calling males were found in temporary ponds and small puddles after heavy rains, throughout the rainy season. Males called in a somewhat vertical posture, with the upper half of the body inside the water (Fig. 31). Voucher specimen: ZUEC 12032.

\section{Elachistocleis cf. ovalis}

This small frog (SVL males $=28.1 \mathrm{~mm}, \mathrm{SD}=3.2$ $\mathrm{mm} ; \mathrm{N}=29$; SVL females $=33.9 \mathrm{~mm}, \mathrm{SD}=4.7 \mathrm{~mm} ; \mathrm{N}=30$; Fig. 33) was commonly captured by pitfall traps throughout the reserve. Males called from temporary ponds and swamps from the middle to the end of the rainy season. Males generally called from sheltered sites at ground level. Some amplectant pairs were observed laying eggs in temporary ponds at approximately 23:00h. Additional information on the biology of Elachistocleis cf. ovalis was provided by Rossa-Feres \& Jim (2001) and Eterovick \& Sazima (2004). Voucher specimen: ZUEC 12031.

\subsection{HABITAT USE}

Among the anuran species observed at EEI (28 spp.), only six were found in gallery forests (Fig. 3): B. ornatus, $H$. albopunctatus, H. lundii, Scinax cf. berthae, Physalaemus cuvieri and Proceratophrys sp). The level of dependence on gallery forests varies among those six species. The range of dependence level was divided into three categories: 1 ) totally dependent, 2) semi-dependent, and 3) incidental (e. g., Silva \& Bates 1995; Brandão \& Araújo 2000).

Only one species, $H$. lundii, could be considered as totally dependent of gallery forests. This species uses gallery forests during all phases of its life cycle (eggs, tadpoles, metamorphs, and adults). The exclusive occurrence 
of $H$. lundii in gallery forests was also observed in central Brazil (Brandão \& Araújo 1998, 2000, Colli et al. 2002, Bastos et al. 2003).

Proceratophrys sp. was considered semi-dependent of gallery forests. Although its tadpoles develop in gallery forests, adults are found in campo sujo areas surrounding these forests. Many amplectant pairs of this species were found in pitfall traps located at the border of these forests. These frogs were probably moving to gallery forests for oviposition. Bufo ornatus had never been observed to breed in gallery forests, although adults and froglets were found in these forests at EEI, indicating that this species may breed in this habitat; if this is true, it would be considered semidependent of gallery forests.

Three species which breed in both gallery and open habitats were classified as incidental of gallery forests: $H$. albopunctatus, Scinax cf. berthae, and P. curvieri. Calling males of $H$. albopunctata were found inside or near gallery forests around permanent ponds. Both Scinax cf. berthae and P. cuvieri were incidentally found breeding in gallery forests.

In the EEI, Proceratophrys sp. and $H$. lundii were found only in the gallery forest that does not flood during the rainy season. On the other hand, B. ornatus was recorded only in the floodable gallery forest. Hypsiboas albopunctatus was found in both types of gallery forest.

The remainder species occurred in all types of open vegetation. Anurans at EEI utilized various types of breeding sites (Table 1). Most hylids (12 of 14 species, 91.6\%) bred in lentic habitats (e. g. temporary and permanent ponds, and swamps). Only $H$. lundii used streams in gallery forests for reproduction. On a single occasion, males of Scinax cf. berthae were found calling near streams.

Most leptodactylids used temporary ponds and puddles for reproduction, with the exception of Proceratophrys sp. which bred in streams. Leptodactylus furnarius preferred swampy areas, whereas the other species in the fuscus group (L. fuscus and L. mystacinus) used primarily shallow temporary ponds. Most Physalaemus species bred in ponds and temporary puddles. However, $P$. cuvieri used all habitat types for reproduction. Both species of microhylids used temporary and permanent ponds, temporary puddles, and swamps for reproduction. Bufo ornatus was found near streams, and $B$. schneideri near ponds and puddles.

Most species at EEI were habitat generalists. Possible this is an adaptation to unstable and unpredictable ephemeral habitats (Levins 1968) which show intense variation in hydroperiod. The ability to use many breeding habitats may facilitate the colonization of new areas (RossaFeres, 1994). Most species found in pristine habitats in the EEI are also found in the anthropogenic water bodies in the surroundings of the reserve, despite the generally small size of those water bodies and the presence of exotic and invasive plant species (Bracchiaria and Pinnus) in and around the water bodies.

\subsection{REPRODUCTIVE ACTIVITY}

All species presented predominantly nocturnal calling activity. Some species, as Proceratophrys sp. and L. fuscus, called also in the morning (up to 9:00h), and in the afternoon (after 15:00h). Most species also called during daytime when sunlight was blocked by dark thunderstorm clouds.

The Itirapina-Brotas region experiences marked dry and wet seasons, consistent with other Cerrado areas. The only permanent water bodies during the dry season were the streams inside gallery forests and a few permanent ponds associated with those streams. However, only a few species bred in these permanent ponds and in the streams to which they were associated. Since most species in the Itirapina-Brotas region bred in temporary ponds and puddles, the reproductive period is always limited to the rainy season (October to March, Table 1, except for $H$. lundii, which seems to breed throughout the year), when these water bodies are formed. Furthermore, the beginning of anuran reproductive season for many species was driven by the onset of the wet season.

We detected a taxon-specific pattern for vocalization and breeding activity at EEI. In general, leptodactylids vocalized in the first half of the rainy season (onset to middle) while hylids and microhylids called during the second half of the rainy season (middle to end). This pattern was also observed in other studies on anurans breeding in ephemeral habitats; it seems to reflect the reproductive strategy for each group, which could be related to phylogenetic constraints. Leptodactylid eggs frequently develop in foam nests on water surface or inside dug-out burrows; tadpoles develop rapidly in the foam nest, which offer protection from dehydration. These two characteristics allow reproduction at the beginning of the raining season, when water availability is limited and more unpredictable. In contrast, the gelatinous eggs of hylids and microhylids in the EEI are deposited underwater or on the water surface. For these species, tadpole development is slower and dependent on water availability. On most years, this condition occurs only around the middle of the rainy season.

\subsection{COMPARISON WITH OTHER FROG ASSEMBLAGES}

Considering species composition, the frog assemblage of EEI is more similar to those of other Cerrado areas and other open ecosystems (e. g. Caatinga) than to those of forests, as expected (Fig. 34). Even assemblages of forest 
areas that are much closer (e. g. Intervales, about $250 \mathrm{~km}$ far from EEI) than some Cerrado areas (e. g. Maracá, over 4000 $\mathrm{km}$ far from EEI) are less similar to the EEI assemblage. Among the frog assemblages of open areas, those located in the northern part of the country (Maracá, São José do Bonfim and Maturéia) are more similar to each other than those situated in Central and southeastern Brazil, despite the fact that two distinct types of open ecosystems (Caatinga and Cerrado) are included in the northern region. Among assemblages of Cerrado areas, the EEI assemblage is more similar to those of three central Brazil assemblages (Águas Emendadas, Silvania, and Manso) than to that of a closer locality (Canastra), mainly because the latter include areas of rocky fields in which many endemic frog species occur (see Haddad et al. 1988).

\section{ACKNOWLEGMENTS:}

We are grateful to Instituto Florestal, especially Denise Zanchetta, for permission to work at the Estação Ecológica de Itirapina and providing logistic support. We also thank IBAMA for the permit to collect specimens (02027.010426/99-21). Many people contributed to this paper with suggestions, information, and field work, especially Graziella Giraldelli, Felipe Spina, Carol Monteiro, Vagner Ariedi Jr., Alexandro Tozetti, Glauco Machado, Vinicius Bonato, Cynthia Prado, and Cristiano Nogueira. Katia Ferraz and Jeanne Robertson helped with the English version. Katia Ferraz and Norberto Hülle helped in drawings and figures. Célio Haddad helped in frog identification. Ivan Sazima, Alexandro Tozetti, and Luis Felipe Toledo provided photographs of frogs. CAB and RJS thank Fapesp, and MCK and MM thanks CNPq for fellowships. Most of the fieldwork was funded by FAPESP and CNPq. Additional funding was provided by the Graduate Program in Ecology, Instituto de Biociências, University of São Paulo, and the Neotropical Grassland Conservancy. This is publication number 8 of the project "Ecology of the Cerrados of Itirapina”.

\section{LITERATURE CITED}

Almeida, M.T. de \& Nunes, R. 1999. Osteocephalus langsdorffi. Herp. Rev.30 (3):173

Arzabe, C. 1999. Reproductive activity patterns of anurans in two different altitudinal sites within the Brazilian Caatinga. Rev. Bras. Zool. 16(3): 851-864.

Bastos, R. P., Motta, J. A. de O., Lima, L. P. \& Guimarães, L. D. 2003. Anfíbios da Floresta Nacional de Silvânia, estado de Goiás. Goiânia: R.P. Bastos.

Barreto, L. \& Andrade, G.V. 1995. Aspects of the reproductive biology of Physalaemus cuvieri (Anura, Leptodactylidae) in northeastern Brazil. Amphibia-Reptilia, 16(1):67-76.
Bertolucci, J.A. 2001. Anfíbios Anuros. In Intervales/ Fundação para Conservação a Produção Florestal do Estado de São Paulo - São Paulo - SP: A Fundação Florestal. p.159-167.

Bokermann, W.C.A. 1962. Observações biológicas sobre “Physalaemus cuvieri” Fitz., 1826 (Amphibia, Salientia). Rev. Bras. Biol. 22(4): 391-399.

Brandão, R.A. \& Araújo, A.F.B. 1998. A herpetofauna da Estação Ecológica de Águas Emendadas. In Estação Ecológica de Águas Emendadas: História Natural de um Fragmento de Cerrado do Brasil Central. (J. Marinho-Filho, F. Rodrigues \& M. Guimarães) GDF, Brasília, DF, Brasil.

Brandão E.A. \& Araújo A.F.B. 2000. A herpetofauna associada às Matas de Galeria no distrito Federal. In Cerrado: caracterização e recuperação de Matas de Galeria. (J.F. Ribeiro, C.E.L. da Fonseca \& J.C.SousaSilva) Embrapa, Brasília, DF p -561-606

Cardoso A.J. 1981. Biologia e sobrevivência de Physalaemus cuvieri Fitz, 1826 (Amphibia, Anura), na natureza. Cien. Cult., 33: 1224-1228.

Cardoso, A.J. \& Haddad, C.F.B. 1984. Variabilidade acústica em diferentes populações e interações agressivas de Hyla minuta (Amphibia, Anura). Ciência e Cultura 36(8):1393-1399.

Cechin, S.Z. \& Martins, M. 2000. Eficiência de armadilhas de queda (pitfall traps) em amostragens de anfíbios e répteis no Brasil. Revta. Bras. Zool. 17:729-740.

Colli, G.R., Bastos, R.P. \& Araújo, A.F.B. 2002. The character and dynamics of Cerrado herpetofauna. In The Cerrados of Brazil: Ecology and Natural History of a Neotropical Savanna (P.S. Oliveira \& R.J. Marquis eds). Columbia University Press. New York. p. 223-241

Dinerstein, E., Powell, G., Olson, D., Wikramanayake, E., Abell, R., Loucks, C., Underwood, E., Allnutt, T., Wettengel, W., Ricketts, T., Strand, H., O’Connor, S. \& Burgess, N. 2000. A workbook for conducting biological assessments and developing biodiversity visions for ecoregion-based conservation. Conservation Science Program, World Wildlife Fund-US, Washington, DC, USA.

Duellman, W. \& Trueb, L. 1994. Biology of Amphibians. New York: McGraw-Hill Book Company.

Eiten, G. 1972. The Cerrado vegetational of Brazil. Bot. Rev. 38:201-341.

Eterovick, P.A. \& Sazima, I. 2004. Anfíbios da Serra do Cipó, Minas Gerais - Brasil. Editora PUCMINAS. 150pp.

Freitas, E.F.L., Spirandelli-Cruz, E.F. \& Jim, J. 2001. Comportamento reprodutivo de Leptodactylus fuscus (Schneider, 1799) (Anura:Leptodactylidae). Com. Mus. Cienc. Tecnol. PUC-RS, Ser. Zool. 14(2):121-132.

Furley, P.A. \& Ratter, J.A. 1998. Soil resources and plant communities of the central Brazilian cerrado and their development. J. of Biogeogr. 15:97-108.

Giaretta, A.A. \& Kokobum, M.N. de C. 2003. Reproductive ecology of Leptodactylus furnarius Sazima \& Bokermann, 1978, a frog that lays eggs in underground chambers (Anura:Leptodactylidae). Herpetozoa 16 (3/4): 115-126. 
Giaretta, A.A. \& Menin, M. 2004. Reproduction, phenology, and mortality sources of Physalaemus (Anura: Leptodactylidae). J. Nat. Hist. 38: 1711-1722.

Greenberg, C.H., Neary, D.G. \& Harris, L.D. 1994. A comparison of herpetofaunal sampling effectiveness of pitfall, single-ended, and double-ended funnel traps with drift fences. J. Herpetol. 28:319-324.

Haddad, C.F.B., Andrade, G. \& Cardoso, A.J. 1988. Anfíbios anuros do Parque Nacional da Serra da Canastra, estado de Minas Gerais. Brasil Florestal 64:9-20.

Heyer, W.R., Donnelly, M.A., Mcdiarmid, R.W., Hayek, L.C. \& Foster, M.S. 1994. Measuring and monitoring biological diversity: standard methods for amphibians. Smithisonian Institution. 364pp.

Levins, R. 1968. Evolution in changing environments, some theoretical explorations. Monogr. Pop. Biol. 2: 1-120.

Kovach, W.L. 1999. MVSP - A multi-variate statistical package for windows, ver. 3.1. Kovach computing Services, Penthraeth.

Kronka, F.J.N., Nalon, M.A., Matsukuma, C.K. 1998. Áreas de domínio do cerrado no Estado de São Paulo. Secretaria do Meio Ambiente - São Paulo, SP.

Lucas, E.M. 2004. Ecologia reprodutiva de três espécies simpátricas de Leptodactylus do grupo fuscus em remanescente de Cerrado no estado de São Paulo. Dissertação de Mestrado. Universidade de São Paulo, São Paulo, SP.

Martins, M. 1988. Biologia reprodutiva de Leptodactylus fuscus em Boa Vista, Roraima (Amphibia: Anura). Rev. Brasil. Biol. 48:969-977.

Martins, M. 1993a. Observations on nest dynamics and embryonic and larval development in the nest building Gladiator frog, Hyla faber. Amphibia-Reptilia 14:411-421.

Martins, M. 1993b.Observations on the reproductive behavior in the Smith frog, Hyla faber. Herp. J. 3: 31-34.

Martins, M. 1998. The frogs of the Ilha de Maracá. In Maracá: The biodiversity \& environment of Amazonian Rainforest (W. Milliken \& J. Ratter, eds). P-285-306.

Martins, M. \& Haddad, C.F.B. 1988. Vocalization and reproductive behaviour in the smith frog, Hyla faber Wied (Amphibia:Hylidae). Amphibia-Reptilia 9: 49-60.

Martins, M., Sazima, I. \& Engler, S.G. 1993. Predators of the nest building gladiator frog, Hyla faber, in southeastern Brazil.Amphibia-Reptilia, 14:307-309.

Martins, M., Pombal Jr, J.P. \& HADDAD, C.F.B. 1998. Escalated aggressive behavior and facultative parental care in the nest building gladiator frog, Hyla faber. AmphibiaReptilia, 69:1-9.

Martins, M., Pombal Jr, J. P. \& HADDAD, C.F.B. 1998. Escalated aggressive behavior and facultative parental care in the nest building gladiator frog, Hyla faber. AmphibiaReptilia, 69:1-9.

Mittermeier, R.A., Myers, N., Mittermeier, C.G. 2000. Hotspots: Earth's biologically richest and most endangered terrestrial ecorregions. Mexico City: CEMEX.
Moreira, G. \& Barreto, L. 1996. Seasonal variation in nocturnal calling activity of savanna anuran community in central Brazil. Amphibia- Reptilia 18:49-57.

Myers, N., Mittermeier, R.A., Mittermeier,C.G., da Fonseca G.A.B., Kent, J. 2000. Biodiversity hotspots for conservation priorities. Nature 403: 853-858.

Ratter, J.A., Ribeiro, J.F. \& Bridgewater, S. 1998. The Brazilian Cerrado vegetation and threats to its biodiversity. Ann. Bot. 80:223-230.

Rossa-Feres, D.C. 1997. Ecologia de uma comunidade de anfíbios anuros da região do Estado de São Paulo: microhabitat, sazonalidade, dieta e nicho multidimensional. Tese de doutorado. Universidade Estadual Paulista, Rio Claro, SP.

Rossa-Feres, D.C. \& Jim, J. 2001. Similaridade do sítio de vocalização em uma comunidade de anfíbios anuros na região noroeste do Estado de São Paulo, Brasil. Revta. Bras. Zool. 18(2):439-454.

Rossa-Feres, D.C., Menin, M. \& Izzo, T.J. 1999. Ocorrência sazonal e comportamento territorial em Leptodactylus fuscus (Anura, Leptodactylidae). Ilheringia, Sér. Zool., 87: 93-100.

Silva, J.M. \& Bates, J.M. 2002. Biogeographic patterns and conservation in the South American Cerrado: a Tropical savanna hotspot. BioScience. 52:225-233.

Sneath P.H.A\& Sokal, R.R. 1973. Numerical Taxonomy. Freeman, San Francisco.

Strussmann, C. 2000. Herpetofauna. In Fauna Silvestre da região do Rio Manso- MT.(Alho, C.J.R, ed). Edições Ibama, Brasília, DF. p-153-189.

Toledo, L.F., Zina, J. \& Haddad, C.F.B. 2003. Distribuição Espacial e Temporal de uma comunidade de anfíbios anuros do Município de Rio Claro, São Paulo, Brasil. Holos Envir. 3 (2): 136-149.

Wolda, H. 1981. Similarity indices, sample size and diversity. Oecologia. 50:296-302.

Title: Amphibians of an open Cerrado fragment in southeastern Brazil

Authors: Cínthia Aguirre Brasileiro, Ricardo J. Sawaya, Mara C. Kiefer, Marcio Martins

Biota Neotropica, Vol. 5 ( number 2): 2005

http://www.biotaneotropica.org.br/v5n2/pt/ abstract?article+BN00405022005

Date Received 03/07/2005 - Revised 05/06/2005

Accepted 07/01/2005

ISSN 1676-0611 